\title{
Field observations of moult cycle, feeding behaviour, and diet of small juvenile tiger prawns Penaeus semisulcatus in the Embley River, Australia
}

\author{
D. S. Heales*, D. J. Vance, N. R. Loneragan \\ CSIRO Division of Fisheries, Cleveland Marine Laboratories, PO Box 120, Cleveland, Queensland 4163, Australia
}

\begin{abstract}
Juvenile tiger prawns Penaeus semisulcatus $(2.5$ to $5.5 \mathrm{~mm}$ carapace lengthi were collected on an intertidal seagrass bed in the Embley River estuary in the Gulf of Carpentarici, Australia. Prawns were sampled every 2 h over one $24 \mathrm{~h}$ period in the pre-wet (early October) and over one $24 \mathrm{~h}$ period in the late-wet season (late March) and the moult cycles and foregut contents determined. Premoult prawns were found mostly between $12: 00$ and 22:00 h and ecdysis occurred mostly between 20:00 and $0: 00 \mathrm{~h}$. A mean moult period of $3.0 \mathrm{~d}$ was estimated from the percentage of the prawns in premoult and ecdysis stages in early evening samples. On a scale of 0 (empty) to 10 (full), the mean foregut fullness of small juveniles was greater than 4.5 during both the day and nught in each season. Copepods, filamentous algae, diatoms and unidentified material were the most common prey in both seasons. Insect larvae were more common in the pre-wet and nematodes and ostracods were more common in the late-wet. Little diel variation in diet was noted. Rapid foregut passage rates under field starvation conditions showed that between 55 and $60 \%$ of foregut contents was cleared in $1 \mathrm{~h}$. This result, and the values for mean foregut tullness over $24 \mathrm{~h}$, suggested that small prawns fed continuously through the day and night. Further field experiments in the presence of food showed that both hard and soft prey items were cleared from the foregut withın $2 \mathrm{~h}$ and also that moult stage affected the feeding behaviour of prawns. Intermoult prawns maintained means of foregut fullness greater than 7 , while premoult prawns ate less.
\end{abstract}

KEY WORDS: Penaeid Juvenile Moult cycle - Moult period $\cdot$ Feeding behaviour - Diet

\section{INTRODUCTION}

The grooved tiger prawn Penaeus semisulcatus is distributed widely throughout the Indo-West Pacific including the Gulf of Carpentaria, Australia, where it is a large part of a valuable commercial trawl fishery (Grey et al. 1983, Somers 1994). Like many commercial penaeid prawns $P$. semisulcatus has a complex life cycle (Dall et al. 1990). Adults spawn offshore and postlarvae enter shallow estuarine and coastal waters where they settle on algal or seagrass beds (Dall et al. 1990, Loneragan et al. 1994, Haywood et al. 1995). In the Gulf of Carpentaria, postlarvae and juveniles are most abundant from September to May (Vance et al. 1996) and spend up to 3 mo in the nursery areas before migrating offshore.

·E-mail: don.heales@qld.ml.csiro.du
The feeding ecology and moult cycle of sub-adult and adult penaeid prawns is well documented and has been reviewed by Dall et al. (1990), but little information exists on feeding and behavioural changes associated with moulting of small juvenile penaeids from either field or laboratory studies.

Adult Penaeus semisulcatus live in deep water habitats and remain buried when light levels are highest during daytime and probably feed mostly at night (Wassenberg \& Hill 1994). The diel feeding cycle of juvenile $P$. semisulcatus is potentially much more complicated than for the adults as they often live in more complex intertidal environments and their activity patterns are not as clearly defined as those of the adults (Vance et al. 1994). The time available for feeding by juveniles may therefore be affected by variable periods of tidal inundation of nursery areas as well as increased moult cycle rates when compared to adults. 
Chong \& Sasekumar (1981) reported that foreguts of small juvenile $P$. merguiensis in estuaries were more than half-filled during the day, but drew no conclusions about their diel feeding cycle. Reymond \& Lagardere (1990) noted that juvenile $P$. japonicus in pond situations fed continuously during the day and night. O'Brien (1992) noted that of 120 foreguts from juvenile $P$. esculentus collected during the day and night on seagrass beds, only 6 were empty.

Moulting condition also affects feeding in penaeids (Dall et al. 1990). Juvenile penaeids moult frequently with moult periods of less than $4 \mathrm{~d}$ being recorded for $5 \mathrm{~mm}$ carapace length (CL) Penaeus merguiensis in the laboratory (Staples \& Heales 1991).

The diet of larger juvenile Penaeus semisulcatus from seagrass beds has been described by Wassenberg $\&$ Hill (1987) and the diets of a wide size range of juvenile $P$. esculentus which occupy similar habitat to $P$. semisulcatus have also been described (O'Brien 1994). Common prey items for these smaller $P$. esculentus juveniles included copepods, bivalves, gastropods, crustaceans, diatoms, filamentous algae, ostracods, and decapods.

This study was undertaken to describe the diet and moult cycle of newly settled Penaeus semisulcatus in their nursery habitats. Changes in foregut fullness, composition of the diet, moult cycle, and moult period were investigated over $24 \mathrm{~h}$ periods in the pre-wet and late-wet seasons. The wet season from January to March has a substantial impact on the marine ecosystem of the north-eastern Gulf of Carpentaria. The two $24 \mathrm{~h}$ series were carried out before, and towards the end of the wet season to test whether the suite of prey items of small tiger prawns was influenced by it. To better understand changes in foregut fullness, field experiments were carried out to investigate foregut clearance rates of these small tiger prawns in the presence of food and also whilst starved.

\section{MATERIALS AND METHODS}

Juvenile grooved tiger prawns Penaeus semisulcatus were collected in the Embley River, north-eastern Gulf of Carpentaria $\left(12^{\circ} 43^{\prime} \mathrm{S}, 141^{\circ} 53^{\prime} \mathrm{E}\right)$ from an intertidal seagrass bed (mostly Enhalus acoroides). Prawns were between 2.5 and $5.5 \mathrm{~mm}$ CL (Table 1 ).

24 h samples. Moult stages, diet, and feeding behaviour patterns were examined and moulting frequency and foregut fullness estimated from samples taken on the seagrass bed every 2 h over one $24 \mathrm{~h}$ period in the pre-wet season (October 1993) and one $24 \mathrm{~h}$ in the latewet season (March 1994). Sampling commenced at 16:00 h and continued until 16:00 h the following day, giving a total of 13 samples per series. Both sets of 13 samples were taken on the full moon and on neap tides to standardise any effects of these variables on feeding behaviour (Vance et al. 1994). Water temperature, salinity, depth and cloud cover were recorded for each sample.

A beam trawl ( $1 \mathrm{~m}$ by $0.5 \mathrm{~m}$ opening and $2 \mathrm{~mm}$ mesh with a $1 \mathrm{~mm}$ codend) towed behind a small boat was the main sampling method and ensured the quick collection of an adequate sample in most cases. However. beam trawling was not possible on low tides when water depth was less than $0.5 \mathrm{~m}$, and a hand-held scoop net $(0.4 \mathrm{~m}$ by $0.4 \mathrm{~m}$ opening and $2 \mathrm{~mm}$ mesh) was used at those times. In the pre-wet season, pairs of samples using both the beam trawl and the hand scoop were taken whenever possible to test for differences in the 2 methods of collection.

Trawl and hand scoop shots were always less than 2 min and sufficient shots were made to collect at least 10 prawns in each 2 hourly sample. Prawns were collected live from the sorting tray and then snap frozen in an iced brine slurry $\left(-8^{\circ} \mathrm{C}\right)$. Samples were transferred in dry ice to the laboratory as soon as possible, where they were stored in an ultra-low freezer at $-50^{\circ} \mathrm{C}$ until processing.

Moult staging. Prawns were thawed, then measured to the nearest $0.1 \mathrm{~mm}$ (CL) using a dissecting microscope fitted with an ocular micrometer. In the pre-wet 24 h series, prawns were moult staged into 3 groups: premoult, ecdysis, and others. Premoult prawns in 
stages D2 to D4 (Dall et al. 1990) had easily identifiable new epicuticles and exocuticles under their carapaces. Prawns in ecdysis had just moulted and were soft-shelled. The third group contained prawns at all other moult stages (Dall et al. 1990).

late-wet season prawns were moult staged in more detail following Dall et al. (1990). In addition to premoult and ecdysis prawns being identified, postmoult prawns were also separated from the other stages.

Results from the pre-wet $24 \mathrm{~h}$ collection had shown that premoult and ecdysis prawns were most abundant between 16:00 h and 20:00 h. In the analysis of the percentage of prawns in premoult (stages D2 to D4) or ecdysis from these studies, a test of 2 unpaired ratios (Armitage \& Berry 1987) was used to determine if there were differences between the prawns from beam trawls and hand scoops at the same time. The ratios did not differ significantly ( $p>0.05$ ) between collection methods, and therefore the data on stage of the moult cycle for beam trawls and hand scoops were pooled. For each sampling time, the numbers of animals from all samples taken at that same time were pooled. The mean proportion of prawns about to moult or having just moulted at a given sampling time was calculated as the number of combined premoult and ecdysis stage prawns divided by the total number in the pooled sample for that time. Additional samples were collected using the beam trawl at 17:00 h and 20:00 h over 3 consecutive nights on the new moon in April 1994 to provide further information on moult frequency

Foregut fullness and diet. After moult staging, the foregut was dissected and emptied on to a $1 \mathrm{~mm}^{2}$ Sedgewick Rafter slide. Foregut fullness by volume was visually estimated by the same person in every case, using a stereo microscope. An index of 0 to 10 corresponded to the qualitative range of empty to full foreguts (Marte 1980). The foregut was then opened and dilute Rose Bengal was added to the spilled contents to stain for animal protein. The contents were teased apart, spread out and scored using a compound microscope.

There is a sound biological basis for separating premoult from intermoult prawns in the analysis of foregut fullness over $24 \mathrm{~h}$ periods. During the late moult stages just prior to ecdysis (stages D2 to D4), prawns reduce or cease feeding and the lining of the foregut is pulled out during the moulting process and a full foregut would therefore hinder the moulting process. Prawns in ecdysis were not included in the analysis of foregut fullness as they were invariably empty. Means of foregut fullness for each sampling time were calculated using SAS statistical package (SAS Institute Inc. 1989) and differences in foregut fullness between moult stages (premoult and intermoult) and seasons (pre-wet and late-wet) were tested by 2 -way analysis of variance. In the late-wet season when postmoult prawns were identified, differences in foregut fullness between intermoult and postmoult prawns were tested by t-test (SAS lnstitute Inc. 1989).

Prey items found in foreguts were very fragmented making the identification and accurate counting of specific prey types difficult. All food items were identified to the lowest taxonomic level. Only those prawns with foregut fullness scores of 7 or higher were included in the diet analysis. Frequency of occurrence (FOC) for each prey item was recorded as the percentage of prawns which had at least 1 of that prey item in their foregut. A Wilcoxon matched-pairs signed-ranks test (Conover 1971) was used to test for differences in FOC between day and night, as well as testing for differences between low tide $(<0.5 \mathrm{~m})$ and high tide $(>0.5 \mathrm{~m})$ at night in both seasons. It was possible to count 2 taxa: foraminaferans and copepods. In general, foraminaferans mostly remained intact while copepod counts were based on the number of carapaces only. The mean numbers for these prey items were calculated for all samples in each season and were based on all prawns in the samples, except for ecdysis stage animals, with foregut fullness scores of 7 or higher. Differences between the number of copepods and foraminaferans in foreguts between the pre-wet and late-wet seasons were tested by Student's $t$-test.

Foregut passage rates. To interpret the $24 \mathrm{~h}$ foregut fullness data it was necessary to have an understanding of the passage rates of food items through the foregut both when the prawns were feeding, and when they were not. We planned to trace the progression of feeding with both Artemia larvae and unhatched cysts as marker prey. Live prawns were collected in the early evening in November 1994, starved for $1 \mathrm{~h}$, and then placed in a large $1 \mathrm{~m}^{3}$ cage constructed with $5 \mathrm{~mm}$ mesh bottom and $2 \mathrm{~mm}$ mesh sides and top. This cage had been embedded into the seagrass substrate $2 \mathrm{~d}$ earlier. Before release, prawns were allowed to feed for $15 \mathrm{~min}$ in a dense solution of 3 to $6 \mathrm{~d}$ old live Artemia larvae and unhatched cysts. At around 20:00 h they were released into the cage to continue feeding. Subsequent examination of foregut contents from prawns taken from inside the cage showed that the range of natural prey items available inside was similar to that occurring on the seagrass outside. A control sample of prawns was frozen in brine slurry at the time of release to test whether the prawns had ingested Artemia larvae and/or cysts. Samples of prawns were removed from the cage after 1 and $2 h$ and immediately frozen.

The food passage rate whilst starved was determined in November and December 1994. Live prawns were collected in a series of 1 min trawls at around 18:00 h. A control sample was frozen in brine slurry immediately, 
and the remaining prawns were starved while being held in ambient temperature seawater. Samples were taken and immediately frozen each hour over a $4 \mathrm{~h}$ period. In the November experiment prawns were held in a black polythene $20 \mathrm{l}$ drum in unfiltered seawater. In the December experiment prawns were held in groups of 20 in buckets of seawater filtered through a $1 \mu \mathrm{m}$ filter. Temperature and salinity were recorded at the beginning and end of both experiments

After thawing in the laboratory prawns from both experiments (the food passage whilst feeding and whilst starved) were separated into 1 of 4 moult stage groups: premoult (stages D2 to D4), which would have moulted on the night of sampling; ecdysis; postmoult; intermoult (stages C, D0 and D1) (Dall et al. 1990), which would not have moulted on the night of sampling. Foregut fullness was estimated, diet contents were scored, FOC of Artemia larvae was calculated, and the number of Artemia cysts and copepod carapaces counted, using the same methods as those described earlier. Recently ingested Artemia larvae could be counted in the control sample at time 0 , but not after 1 or $2 \mathrm{~h}$ as the carapaces had been crushed. Consequently, FOC was used as an index of passage rates. In the continuous feeding regime, the passage rate of food through the foregut was calculated as the time taken for the marker prey, either Artemia larvae or cysts, to disappear from the foregut. In the 2 starvation experiments, the means of foregut fullness for the intermoult prawns sampled at the same time were not significantly different $(p>0.05)$ and thus were pooled. The number of premoult prawns in each starvation experiment was low and so these were also pooled for the estimates of foregut fullness. For the intermoult prawns from the 2 starvation experiments, differences in foregut fullness were tested by t-test (SAS Institute Inc. 1989)

\section{RESULTS}

\section{Environment}

The tidal pattern was similar for both $24 \mathrm{~h}$ series with low tides occurring after mid-day (12:00 to 14:00 h) and mid-night $(0: 00$ to $02: 00 \mathrm{~h})$. Temperature throughout the $24 \mathrm{~h}$ ranged from 21.8 to $31.0^{\circ} \mathrm{C}$ (mean $=26.1^{\circ} \mathrm{C}$ ) in the pre-wet, and from 29.4 to $34.5^{\circ} \mathrm{C}$ (mean $=31.0^{\circ} \mathrm{C}$ ) in the late-wet. Maximum. temperatures were recorded near the time of low tide during the day $(12: 00$ to $14: 00 \mathrm{~h})$, but dropped rapidly soon after Salinity in the pre-wet varied little from 36.5 to $37.6 \%$ over the $24 \mathrm{~h}$ and was lower in the late-wet at around $30 \%$ for most of the $24 \mathrm{~h}$.

Temperature for all other samples ranged from 29.7 to $34.0^{\circ} \mathrm{C}$ and salinities from 29.0 to $36.4 \%$.

\section{Moult cycle}

Premoult and ecdysis stage prawns were mostly taken between 16:00 and 22:00 h. The pooled ratios (of combined premoult and ecdysis stage prawns to the whole sample size) were 1:4.1 ( $\mathrm{n}=114)$ for the pre-wet, and $1: 4.4(n=101)$ for the late-wet season. In the pre-wet the premoult and ecdysis prawns were captured at different times during the $24 \mathrm{~h}$ period. Most prawns in the premoult stage $(95 \%)$ were taken between $14: 00$ and 22:00 h (Fig 1a), while most prawns in ecdysis (94\%) were taken between 20:00 and 0:00 h (Fig. 1 b). The proportion of prawns in ecdysis in samples increased as the proportion of premoult prawns decreased.

Similarly, in the late-wet all premoult prawns were caught between $06: 00$ and $22: 00 \mathrm{~h}$, with $76 \%$ taken between 14:00 and 22:00 h (Fig. 1c). Prawns in ecdysis were taken only at 20:00 h (Fig. 1d). Postmoult animals were caught only from $22: 00$ to $06: 00 \mathrm{~h}$, with $71 \%$ taken between 22:00 and 02:00 h (Fig. 1e).

\section{Proportion of premoult and ecdysis animals}

The mean proportion of premoult and ecdysis prawns at each sample time, between 16:00 and 20:00 h (i.e. those prawns either about to moult, or those which had just moulted), ranged from 32 to $37.5 \%$ (Fig 2). The number of pooled samples at the 4 sampling times

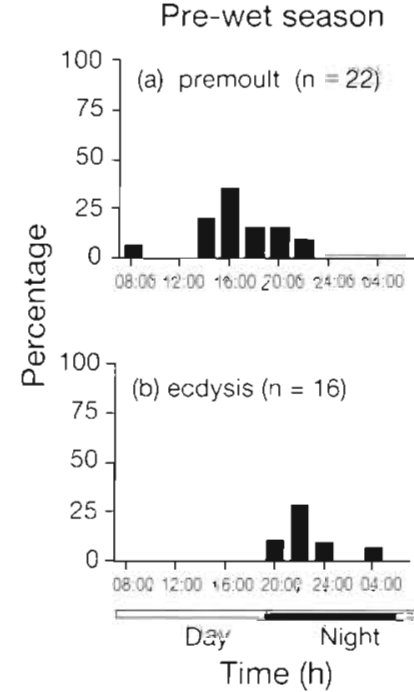

Fig. 1. Penaeus semisulcatus. Proportion $(\%)$ of pre-wet season juvenile prawns in (a) premoult, (b) ecdysis. Proportion (\%) of late-wet season juvenile prawns in (c) premoult, (d) ecdysis and (e) postmoult
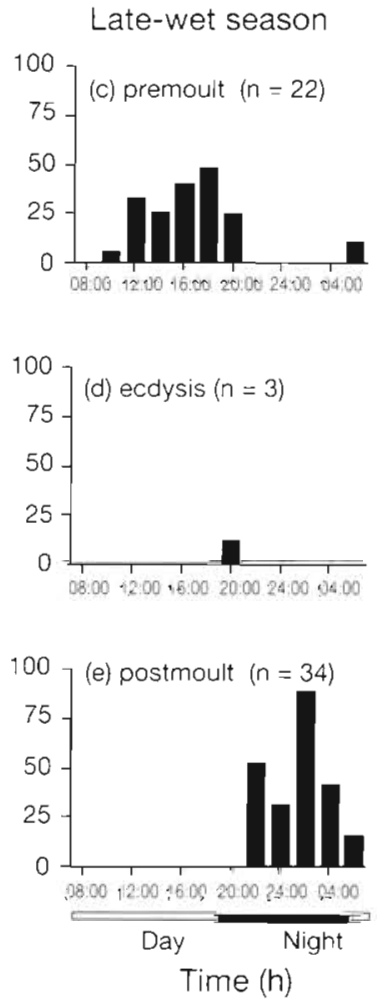
ranged from 2 to 5 , the number of prawns ranged from 55 to 165 , and the total number of prawns caught was 399.

\section{Foregut fullness}

All prawns in ecdysis $(n=19)$ that were examined had empty foreguts. For other moult stages, there were no consistent differences in foregut fullness between samples of prawns caught with the beam trawl and the hand scoop, nor were there any differences between patterns for the pre-wet and the late-wet. In every sample from both seasons the mean index of foregut fullness was higher than 4.5. Analysis of variance showed that the mean foregut fullness did not differ significantly between moult stage $\left(F^{1.155}=0.21\right.$, $\mathrm{p}=0.6)$ and season $\left(F^{1,165}=0.50, \mathrm{p}=0.5\right)$ and the moult $\times$ season interaction was not significant $\left(F^{1,165}=\right.$ $0.01, p=0.9$ ). All samples from both seasons were then pooled for each sample time. The minimum mean foregut fullness, after pooling, throughout the $24 \mathrm{~h}$ was 6.7 and the maximum was 8.5 (Fig 3). The overall mean of foregut fullness $( \pm 1 \mathrm{SE})$ for all moult stages except ecdysis and over both seasons was $7.2 \pm 0.18$.

In postmoult prawns from the late-wet season at times 22:00 to $06: 00 \mathrm{~h}$, the mean foregut fullness of $7.0 \pm 0.3$ was significantly lower than the mean of $8.6 \pm$ 0.3 for intermoult prawns $\left(t^{79}=17.2, p<0.0001\right)$.

\section{Diet}

Prawns caught with the hand scoop and with the beam trawl were pooled in the analysis of dietary

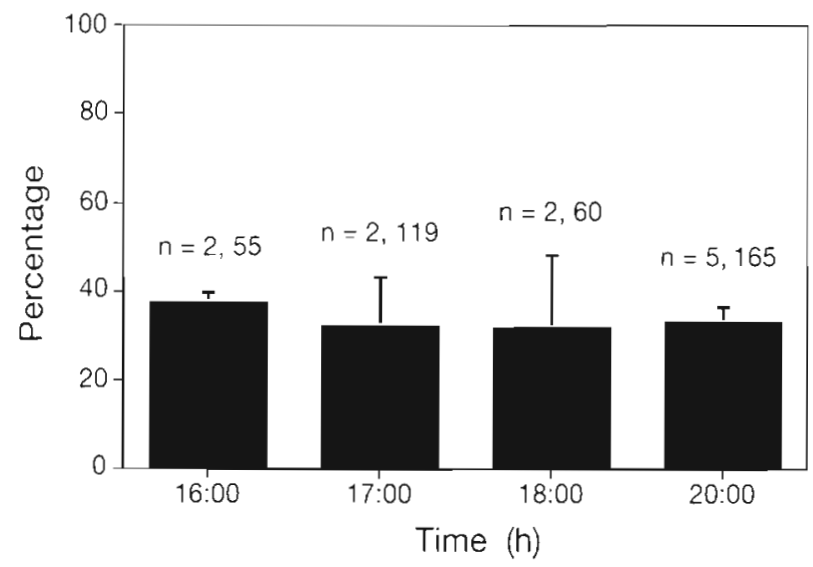

Fig. 2. Penaeus semisulcatus. Mean proportion ( \pm 1 SE) of combined premoult and ecdysis stage juveniles from two $24 \mathrm{~h}$ studies and mid-April sampling $n$ = number of samples, number of prawns at each sampling time

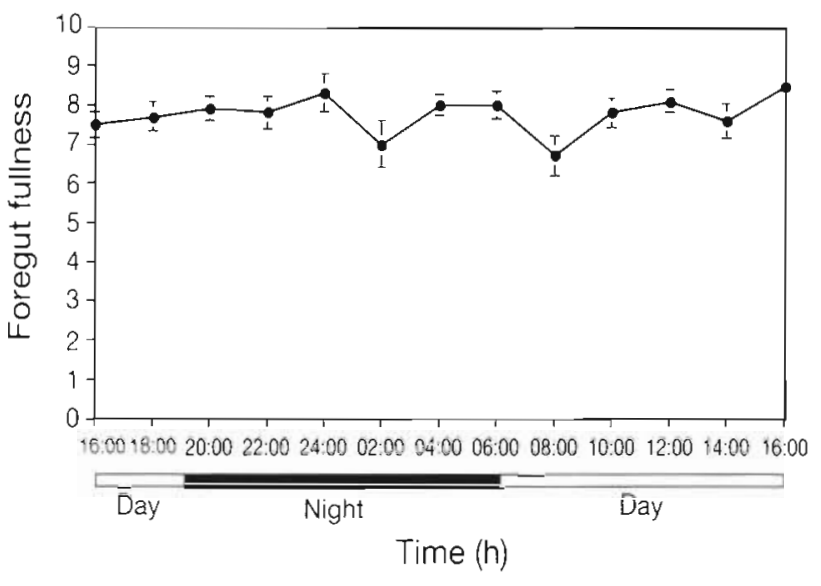

Fig. 3. Penaeus semisulcatus. Mean foregut fullness ( $\pm 1 \mathrm{SE}$ ) for juveniles in all moult stages except erdysis from combined pre-wet and late-wet season 24 h studies; $n$ ranged between 19 and 50 in each sample

items. In all, 19 categories of prey items were identified, with unidentified material, copepods (predominantly Harpacticoid), diatoms (including Pleurosigma, Gyrosigma, Asterionella, Rhizosolenia and Coscinodiscus), filamentous algae, insect larvae (Diptera), nematodes, ostracods, foraminaferans, and an unidentified parasite all having FOC values greater than $25 \%$ in 1 or both of the seasons (Fig. 4). Less common items (FOC less than $25 \%$ ) included decapods, bivalves, gastropods, polychaetes, kinorynchs, unidentified marine mites, seagrass, algae, isopods and amphipods. No sig-

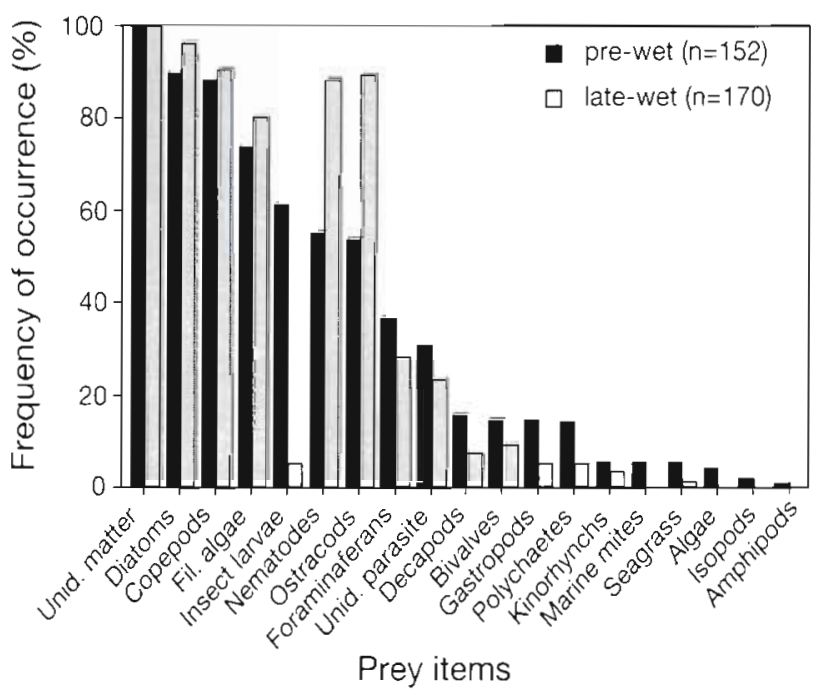

Fig. 4. Penaeus semisulcatus. Frequency of occurrence $(\%)$ of prey items from foreguts of juvenles from 1 pre-wet season and 1 late-wet season 24 h study. Foreguts examined from prawns in all moult stages except ecdysis and with foregut fullness score of 7 or higher 
nificant differences in FOC were detected between day and night (Wilcoxon test $t^{18}=71.5, p>0.05$ ) or between tide heights at night $\left(t^{17}=73.5, p>0.05\right)$ in the 2 seasons.

The types of food eaten in the late-wet 19 categories) were similar to those eaten in the pre-wet season (15 categories). However, the 4 categories not present in the late-wet (marine mites, algae, amphipods and isopods) all had very low FOC (less than $5 \%$ ) in the pre-wet (Fig. 4) Out of 9 categories with an FOC higher than $25 \%$ in at least 1 season only insect larvae, nematodes, and ostracods were markedly different between seasons. The largest change was in FOC for insect larvae, which decreased from $61 \%$ in the prewet to $5 \%$ in the late-wet season. However, the FOC was higher in the late-wet for nematodes (55 to $88 \%$ ) and for ostracods (54 to $89 \%$ ).

The mean number of copepods per foregut was significantly higher in the pre-wet $(12.1 \pm 0.7)$ than in the late-wet season $\left(7.8 \pm 0.7, t^{3 t 1}=20.0, p<0.0001\right)$, and similarly for foraminaferans $(2.1 \pm 0.2$ to $1.3 \pm 0.3$, $t^{108}=6.9, p<0.01$ )

\section{Foregut passage rate with continuous feeding}

Intermoult prawns fed continuously when offered Artemia larvae and cysts whereas premoult prawns did not. At the start of the experiment the foregut fullness mean was higher for intermoult than premoult prawns (Fig 5a). Mean foregut fullness of the premoult group declined through the experiment (Fig. 5a)

Whole Artemia larvae passed through the foreguts of both premoult and intermoult prawns within $2 \mathrm{~h}$ (Fig. 5b). The Artemia, mostly whole, were easily recognised in the control sample at time 0 , where they made up the bulk of the volume in each foregut, but could not be counted because of their condition. Consequently, FOC was used as an indicator of foregut clearance rates. After $1 \mathrm{~h}$, only antennae were discernible, and FOC had decreased to $80 \%$ for intermoult and $35 \%$ for premoult prawns. After $2 \mathrm{~h}$ no traces of Artemia larvae were detected in either the intermoult or premoult prawns. Copepods, diatoms, filamentous algae, forams, ostracods, bivalves, gastropods, decapods and insect larvae were common prey items in foreguts of the intermoult group after 2 h.

Artemia cysts, which are very resistant to digestion, also passed through the foregut within $2 \mathrm{~h}$ for both moult groups (Fig 5c). The whole cysts were easily detected and counted at time 0 , but after $2 \mathrm{~h}$, only a few whole cysts remained. No broken pieces of cysts were observed.
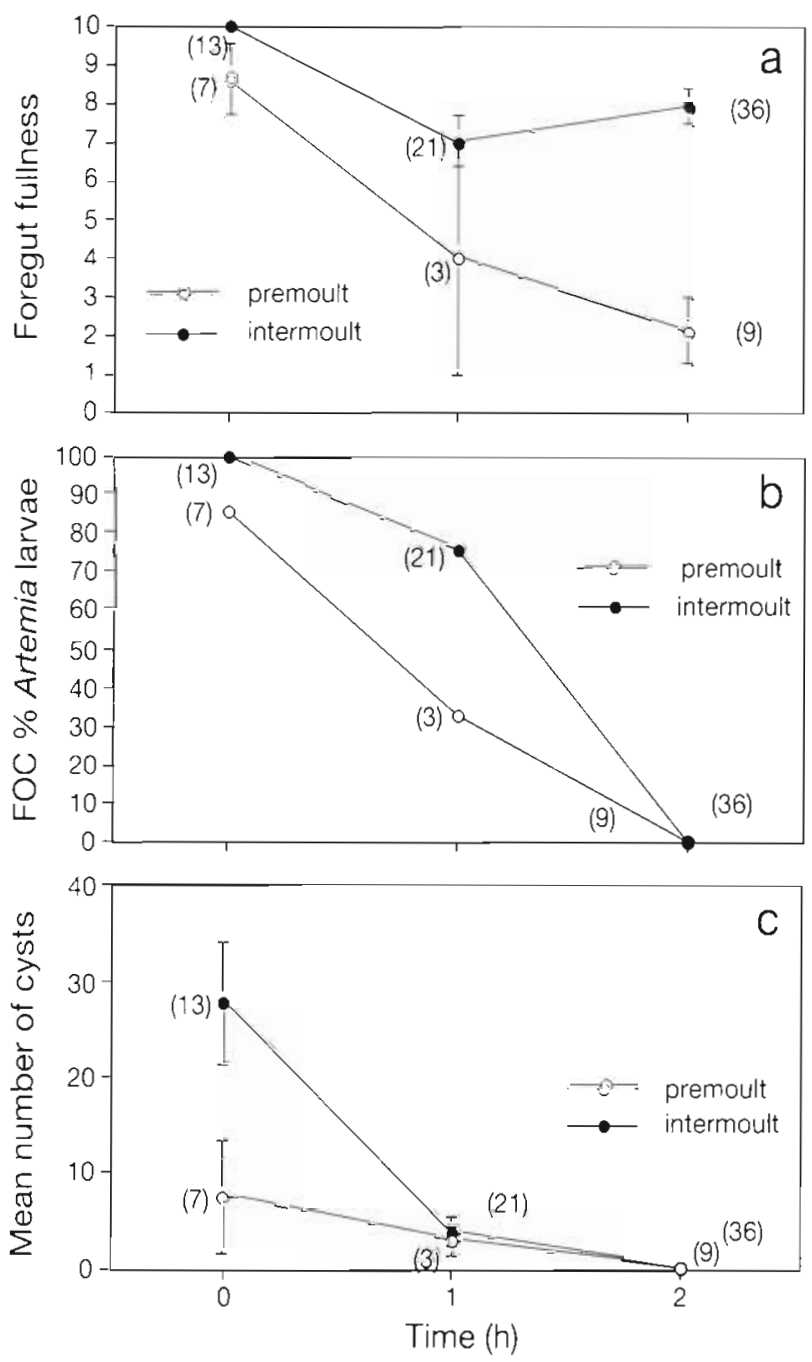

Fig. 5. Penaeus semisulcatus. Foregut passage rate with continued feeding for premoult and intermoult juvenile prawns: (a) means ( $\pm 1 \mathrm{SE}$ ) of foregut fullness, (b) frequency of occurrence $(\%)$ of Artemia larvae, and (c) mean number ( \pm . SE) of cysts per foregut. Numbers in parentheses are numbers of prawns per sample

\section{Foregut passage rate whilst starved}

Means of foregut fullness for both moult stage groups dropped to about 4 after $1 \mathrm{~h}$, and to between 0.3 and 3 after $3 \mathrm{~h}$ (Fig. 6). The foreguts of a few intermoult prawns were still $2 / 3$ full after 3 and $4 \mathrm{~h}$, mostly of a stringy algae and some pieces of decapod exoskeleton. The sharp initial decline in means of foregut fullness continued in the premoult group and had dropped by $95 \%$ after $3 \mathrm{~h}$.

The mean $( \pm 1 \mathrm{SE})$ numbers of copepods per foregut of intermoult prawns fell from $29.4( \pm 2.78)$ at time 0 to $1.0( \pm 0.39)$ at $2 \mathrm{~h}$. For the premoult group, mean numbers of copepods dropped from $11( \pm 2.35)$ per foregut at time 0 to 0 in all prawns at time $2 \mathrm{~h}$ 


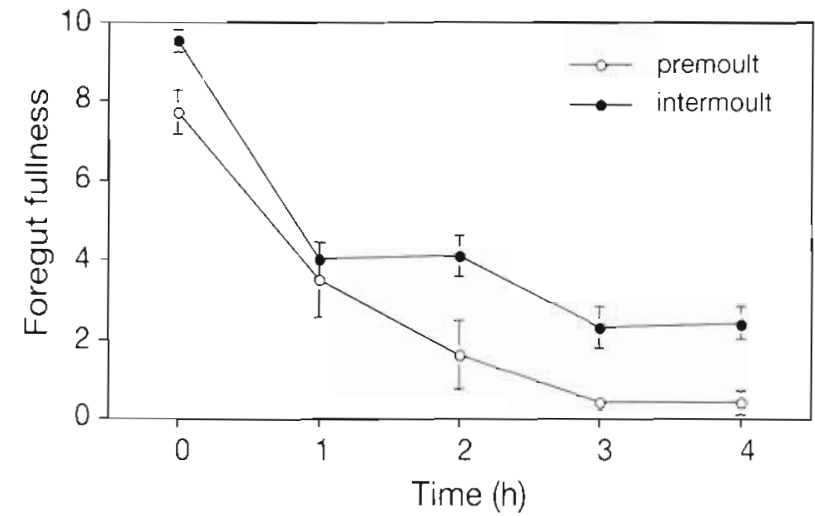

Fig. 6. Penaeus semisulcatus. Foregut clearance of premoult and intermoult juveniles (means of foregut fullness \pm 1 SE). The number of premoult prawns ranged between 9 and 17 per data point and between 34 and 38 for intermoult prawns

\section{DISCUSSION}

\section{Moult stages and cycle}

Juvenile prawns at premoult stage were found only during the day and early evening. Moulting mostly occurred in the first half of the night but some postmoult prawns that had just moulted could still be identified up until dawn. These results broadly agree with the findings of others on the timing of ecdysis in early evening for larger juvenile, sub-adult and adult penaeids (Dall et al. 1990). However, this is the first time that the actual daily timing of the occurrence of the major moult stages has been documented from field observations of a Penaeus species. The low percentage of moulting prawns in both $24 \mathrm{~h}$ series indicates that this stage lasts only a short time in small juveniles and the new exoskeleton hardens rapidly (i.e. in less than $2 \mathrm{~h}$-the interval between our samples). Unlike adult prawns, there was no evidence that small soft-shelled prawns were inactive on the substrate for long periods of time.

Ecdysis reduces the feeding of most adult penaeids. For example, adult Penaeus duorarum did not feed regularly until $36 \mathrm{~h}$ after ecdysis (Bursey \& Lane 1971 ). Feeding was also reduced in adult $P$. esculentus on the 2 nights before ecdysis, ceased on the actual night of ecdysis, and was still reduced on the following night (Hill \& Wassenberg 1992). In juvenile $P$. semisulcatus, the effect is much less marked. Although the mean foregut fullness for postmoult prawns from the late-wet season was high (7.0). it was lower than the mean for intermoult prawns (8.6). This suggested that if the feeding of juveniles was reduced immediately following ecdysis, it was not reduced for very long

\section{Estimation of moult period}

If we assume that the moult period is constant over time for a given range of prawn size and temperature (Staples \& Heales 1991, O'Brien 1992), and that there is no synchronisation of moulting, then the proportion of prawns moulting each day can be used to estimate the moult period in the wild population. Based on these assumptions the moult period will be the reciprocal of the moult frequency in the population. For example, if $50 \%$ of the prawns moult each day, then all prawns will have moulted in $2 \mathrm{~d}$ and the moult period is $2 \mathrm{~d}$. In our study, the mean proportion of prawns moulting each day of sampling ranged from 32 to $37.5 \%$ and the mean $( \pm 1 \mathrm{SE})$ over all $5 \mathrm{~d}$ was $33.4 \pm 1.4 \%$. This suggested a mean moult period of $3.0 \mathrm{~d}$ for 2.5 to $5 \mathrm{~mm}$ CL prawns.

Previous laboratory studies on the growth of juveniles of another tropical species, Penaeus merguiensis (the banana prawn), at different combinations of temperature, salinity and prawn size, have shown that moult period is most dependent on temperature (Staples \& Heales 1991). When we fitted the range of temperature, salinity, and prawn size ffrom our tiger prawn studies) to the equation for moult period in the banana prawn, the period ranged from 2.49 to $3.52 \mathrm{~d}$, which spans the range of our field estimate of a $3.0 \mathrm{~d}$ moult period. Although estimates of moult period are routine in some laboratory growth experiments on penaeids, we have been unable to find any estimates based purely on field observations of a penaeid species.

The consistency of moult frequency between samples on different nights shows no evidence of moult cycle synchronisation. Similarly, no moult synchronisation was detected for small juvenile Penaeus merguiensis kept in separate containers in a laboratory recirculating seawater system (Staples \& Heales 1991). Crocos (1985) also reported that moulting and spawning of adult $P$. esculentus were not synchronised with lunar cycles. However, more recent studies have demonstrated a lunar cycle in the reproduction of adult P. plebejus (Courtney et al. 1996)

\section{Foregut fullness and feeding behaviour}

The mean foregut fullness of small juvenile Penaeus semisulcatus was consistently high across the $24 \mathrm{~h}$ period, which suggests that prawns of this size feed throughout day and night. In contrast, adult $P$. semisulcatus bury and apparently stop feeding during the day (Wassenberg \& Hill 1994). The changeover point in size from non-burying behaviour to burying during the day is unknown for $P$. semisulcatus. However, it may be between 4 and $8 \mathrm{~mm}$ CL as no burying behav- 
iour was observed for $P$. semisulcatus at $4.1 \mathrm{~mm} \mathrm{CL}$ in laboratory studies (Liu \& Loneragan in press). In contrast, almost $70 \%$ of juvenile $P$. semisulcatus (mean size $=8 \mathrm{~mm}$ CL) in laboratory experiments were found to be buried in daylight (Hill \& Wassenberg 1993) Catches of juvenile $P$. semisulcatus (2 to $10 \mathrm{~mm} \mathrm{C.L)}$ with a small beam trawl were higher at night close to low tide (Vance et al. 1994). Our present data suggest that the small juveniles sampled in this study may be active and feeding both day and night.

Small Penaeus semisulcatus digest much of their food within an hour and this would support a continuous feeding behaviour. However, feeding is affected by the moult cycle. Adult $P$. semisulcatus would be expected to behave similarly to adult $P$. esculentus and reduce feeding $2 \mathrm{~d}$ before and $1 \mathrm{~d}$ after ecdysis which occurs about every $21 \mathrm{~d}$ at $28^{\circ} \mathrm{C}$ (Hill \& Wassenberg 1992). However, for small juveniles the short time period between moults (about $3 \mathrm{~d}$ ) probably reduces the lasting period to only 1 or $2 \mathrm{~h}$. Our study did not detect differences between means of foregut fullness of premoult and intermoult prawns in either of the 2 seasons but the sample size was small in both cases.

Differences in feeding behaviour between premoult and intermoult prawns were observed. In the foregut clearance experiments, both where feeding continued and also whilst starved, the premoult prawns almost emptied their foreguts within $2 \mathrm{~h}$ in preparation for imminent ecdysis. In contrast, the intermoult prawns from the continuous feeding experiment had foreguts that were over $2 / 3$ full. The intermoult prawns from the starved experiment also had fuller foreguts than the premoult group after $2 \mathrm{~h}$

The rapid decline in mean foregut fullness of premoult prawns when they were deprived of food (over $50 \%$ in the first hour) showed that the prawns could clear their foreguts by ceasing to feed almost $2 \mathrm{~h}$ before ecdysis.

\section{Diet}

A wide range of prey items was encountered in the foreguts of small juvenile Penaeus semisulcatus. During the course of these studies we commonly observed juvenile tiger prawns at the surface on night high tides but never during the day. We did not categorise prey items such as gastropods, nematodes, and copepods into benthic, plant dwelling, or water column fauna, as in intertidal seagrass habitats, these boundaries vary with tide height. At low tide the long strap-like Enhalus acoroides leaves were close to the substrate and all prey items taken at this time were close to the bottom. At high tide the tips of the seagrass may be up to $1 \mathrm{~m}$ above the substrate and some prey items may become mid-water dwellers as they move with the epiphyte covered seagrass fronds. However, we could not detect any significant differences in the FOC data between day and night, or between the FOC of prawns at high and low tide at night.

The comparison between seasons showed some dietary switches, the major one being for insect larvae. The decline in insect larvae also coincided with increased frequency of occurrence of both nematodes and ostracods. The occurrence data for all other prey items were remarkably similar given the impact of the wet season between the 2 studies. Although the mean numbers of copepods and foraminaferans, the only prey items which could be reliably counted, were higher in the pre-wet than late-wet seasons, the range of prey items in the 2 seasons were very similar

Bivalves, gastropods, ophiuroids and copepods were also recorded with occurrences greater than $50 \%$ in the foreguts of larger juvenile Penaeus semisulcatus (about $13 \mathrm{~mm} \mathrm{CL}$ ) from seagrass beds in the western Gulf of Carpentaria (Wassenberg \& Hill 1987). Frequency of occurrence for copepods fell to below $20 \%$ for the larger size group juveniles (around $18 \mathrm{~mm} \mathrm{CL}$ ) showing the effect of ontogeny. In a study of a closely related tiger prawn species, Penaeus esculentus isize 2 to $5 \mathrm{~mm} \mathrm{CL}$ ) in an Australian seagrass bed, O'Brien (1994) also noted that copepods and diatoms were found in all foreguts. FOC for filamentous algae and ostracods was lower (around $50 \%$ ) and nematodes and insect larvae were not recorded at all (O'Brien. 1994).

Unidentified material was found in every foregut we examined. This matter probably consisted of both animal and plant material, and as such may be important for the nutrition of juvenile tiger prawns. Robertson (1988) reported up to $74 \%$ of detrital floc by volume from juvenile Penaeus merguiensis in northern Australia, but was hesitant to assign a nutritional role to that floc.

\section{Summary}

Our studies of the diet and feeding showed that in both the pre-wet and late-wet seasons juvenile Penaeus semisulcatus fed throughout the day and night at intervals of probably not greater than $3 \mathrm{~h}$. Food passed rapidly through the foregut in less than $2 \mathrm{~h}$ for some hard and soft prey items. Moult stage affected feeding behaviour, with feeding ceasing in prawns undergoing ecdysis. The mean moult period estimated for juvenile prawns in this size range was $3.0 \mathrm{~d}$ and ecdysis occurred in the early evening in most cases. Moulting was followed by a short soft-shelled stage which was completed by midnight and the next stage, postmoult, was completed by dawn the next morning. 
Diet was similar in both seasons and consisted mainly of unidentified matter, copepods, insect larvae, diatoms and filamentous algae. Insect larvae were common food items in the pre-wet and nematodes and ostracods more common in the late-wet season

Acknowledgements. The authors thank D. McGinn, M. ElsonHarris, and Dis P. Hutchings and C. O'Brien for helping with identıfication of prey items. Drs B. Hill, R. Heales and C. O'Bnen provided helpful comments on the manuscript. Funding for this study was provided by the Fisheries Research and Development Corporation of Australia (FRDC grant No $92 / 45)$

\section{LITERATURE CITED}

Armitage P, Berry G (1987) Statistıcal methods in medical research, 2nd edn. Blackwell Scientific Publications, Oxford, p 123-125

Bursey CR, Lane CE (1971) lonjc and protein concentration changes during the molt cycle of penaeus duorarum Comp Biochem Physiol 40A:155-162

Chong VC, Sasekumar A (1981) Food and feeding habits of the white prawn Penaeus merguiensis. Mar Ecol Prog Ser $5: 185-191$

Conover WJ (1971) Practical nonparametric statistics. J Wiley \& Sons, New York

Courtney AJ, Die DJ, MCGilvray JG (1996) Lunar perıdicity in catch rate and reproductive condition of adult eastern king prawns, Penaeus plebejus, in coastal waters of south-eastern Queensland, Australia. Mar Freshwat Res $47: 67-76$

Crocos PJ (1985) Appraisal of some factors relevant to the development of penaeid prawn population reproductive models. In: Rothlısberg PC, Hill BJ. Staples DJ (eds) Second Australian national prawn seminar NPS2, Cleveland, p 159-164

Dall W. Hill BJ, Rothlisberg PC, Staples DJ (1990) The biology of the Penaeidae. In: Blaxter JHS, Southward AJ (eds) Adv Mar Biol 27:1-489

Grey DL, Dall W, Baker A (1983) A guide to the Australian penaeid prawns. Northern Territory Government Printing Office, Darwin

Haywood MDE, Vance DJ, Loneragan NR (1995) Seagrass and algal beds as nursery habitats for tiger prawns (Penaeus semisulcatus and $P$. esculentus) in a tropical Australıan estuary. Mar Biol 122:213-223

Hill BJ, Wassenberg TJ (1992) Preferences and amount of food eaten by the prawn Penaeus esculentus over the moult cycle. Aust J Mar Freshwater Res 43:727-735

Hill BJ, Wassenberg TJ (1993) Why are some prawns found in seagrass? An experimental study of brown (Penaeus

This article was submitted to the editor esculentus) and grooved ( $P$. semisulcatus) tiger prawns Aust J Mar Freshwater Res 44:221-227

Liu H, Loneragan NR (in press) Size and time of day affect the response of postlarvae and early juvenile grooved tiger prawns Penaeus semisulcatus (Decapoda: Penaeidae) to natural and artifical seagrass in the laboratory. J Exp Mar Biol Ecol

Loneragan NR, Kenyon RA. Haywood MDE, Staples DJ (1994) Population dynamics of juvenile tiger prawns (Penaeus esculentus and $P$ semisulcatus) in seagrass habitats of the western Gulf of Carpentaria, Australia. Mar Biol 119:133-143

Marte CL (1980) The food and feeding habit of Penaeus monodon Fabricius collected from Makato River, Aklan Philıppines (Decapoda Natantia). Crustaceana 38:225-236

O'Brien CJ (1992) Some aspects of the production ecology of Penaeus esculentus Haswell (Decapoda: Penaeidae) juveniles. PhD thesis. University of Now South Wales

O'Brien CJ (1994) Ontogenetic changes in the diet of juvenile brown tiger prawns Penaeus esculentus. Mar Ecol Prog Ser 112:195-200

Reymond H, Lagardere JP (1990) Feeding rhythms and food of Penaeus japonicus Bate (Crustacea, Penaeidae) in salt marsh ponds: role of halophilic entomofauna. Aquaculture $84: 125-143$

Robertson AI (1988) Abundance, diet and predators of juvenile banana prawns, Penaeus merguiensis, in a tropical mangrove estuary. Aust J Mar Freshwater Res 39:467-478

SAS Institute Inc (1989) SAS/STAT user's guide, Version 6, 4 th edn. SAS Institute Inc, Cary

Somers IF (1994) Species composition and distribution of commercial penaeid prawn catches in the Gulf of Carpentaria, Australıa, in rolation to depth and sediment type. Aust J Mar Freshwater Res 45:317-335

Staples DJ, Heales DS (1991) Temperature and salinity optıma for growth and survival of juvenile banana prawns Penaeus merguiensis. J Exp Mar Biol Ecol 154:251-274

Vance DJ, Haywood MDE. Heales DS. Staples DJ (1996) Seasonal and annual variation in abundance of postlarval and juvenile grooved tiger prawns Penaeus semisulcatus and environmental variation in the Embley river, Australia: a 6 yr study. Mar Ecol Prog Ser 135:43-55

Vance DJ, Heales DS, Loneragan NR (1994) Seasonal diel and tidal variation in beam-trawl catches of juvenile grooved tiger prawns, Penaeus semisulcatus (Decapoda: Penaeidae), in the Embley River, North-eastern Gulf of Carpentaria, Australıa. Aust J Mar Freshwater Res 45:35-42

Wassenberg TJ, Hill BJ (1987) Natural diet of the tiger prawns Penaeus esculentus and $P$. semisulcatus. Aust $J$ Mar Freshwater Res 38:169-182

Wassenberg TJ, Hill BJ (1994) Laboratory study of the effect of light on the emergence behavour of eight species of commercially important adult penaeıd prawns. Aust J Mar Freshwater Res 45:43-50

Manuscript first recelved: February 9, 1996

Revised version accepted: June 27, 1996 